\title{
How Can English Tell the Story?
}

\author{
Douglas Reed Eldredge
}

Published online: 10 November 2009

(C) Springer Science + Business Media, LLC 2009

It seems that every new high school teacher in the USA suffers an opening barrage of aphorisms. The longer a profession has been around, the more time people have to scribble down turns of phrase about it, and teaching just might be number two or three on "the world's oldest professions" list, although it has often been even less respected than number one. Mostly these aphorisms are serious pieces of advice aimed at new teachers from their older colleagues, nuggets intended to impart a few critical survival techniques in the space of a sentence or two. I remember during my first September hearing such classics as "Don't smile "till Christmas." (It sets the wrong tone, the thinking goes.) "Never raise your voice in the classroom." (If you have to yell, you've already lost control of the room.) There was even one faculty member who thought it was important from the start I was aware that "He who dares teach must never cease to learn." (It's true-teachers actually speak like this sometimes.) The list goes on, and since secondary education in the USA is no streamlined, standardized production, since student populations, school environments, and financial resources vary wildly from town to town, each set of old saws is particular (or peculiar) to your instructional milieu. Still, for novice teachers in the threatening wilds of their first semester, most advice is welcome advice, even if, for instance, you plan on smiling absolutely every day, for pretty much the entire period, at least up to Christmas.

There was one old chestnut that really "zinged" me, though. If an aphorism comes from a successful fifteen-year man with an apologetic disclaimer, you know you are

D. R. Eldredge $(\bowtie)$

Lincoln High School, Jersey City, NJ

e-mail: speareshakes@hotmail.com beyond typical John Dewey quote territory ("Education is not preparation for life, it is life itself!") In my second year of teaching high school English, I was sitting around a department meeting, just sort of cruising on idealism and trying to soak up any good ideas that might be raised. We were discussing how best to teach literature, and as an English major not that far removed from his student days, I had some thoughts on the subject. Then the neophyte section of the room got hit with the secret, internal, overriding teaching aphorism to end all aphorizing. A Head Teacher turned to us and said, "No offense, and I know you guys don't feel this way, but you really don't even figure out how to teach until after your first five years." Excuse me? Was that a dis? I don't know what I'm doing? I didn't speak to him for a month.

At one year I thought that was wrong. At five years, I thought it was probably right, and now at nine years I am very much beginning to wonder about the wisdom of that aphorism again. I now have the sneaking feeling that it is impossible to know how to teach if the subjects themselves are wrong, or at the very least, incomplete. Let me explain.

With one full year under my belt, I thought that particular nugget wasn't just bunk, it was snarky, ageist bunk. One year into the career the young teacher is (hopefully) too full of fearful exhilaration and burbling idealism to waste time wondering if they really know exactly what they are doing. After five years I had to laugh and admit that I mostly agreed: Five years in, you really do hit your stride and find yourself producing that perfect instructional alchemy of semi-mastery of subject matter married to a polished delivery system with the appropriate sprinkling of student discipline. At five years' service you should feel that you have arrived, that you are ideally situated to hold forth on your subject 
forever, or at least until a reasonably early retirement twenty-five years in. Now, with nine years of urging, straining, yearning, and teaching to my eternal credit, I am detecting hints of a sinking pedagogic inadequacy, even as I loudly declaim the Bard with my students and laugh along with them at the beautiful and bawdy Chaucer (both of those guys still go over fairly well in the modern English classroom). It is not my passion for the subject that leaves me feeling "it's not enough." Nor is it any dimming of my love of the particular writers, poets, and artists we spend our days discussing. I just came off an extremely long summer vacation, so there is plenty left in the tank-I am far from burning out, and I find myself thrilled to have miles to go before I put teaching English to sleep. No, what accounts for my newfound suspicion that I'm not as good a teacher as I might be is the belated remembrance that my subject simply isn't "enough." I realize something now that I half thought during my student teaching days, that high school English, lilting and lovely as it is, fixates too much on stories and thus fails in its potential to tell The story.

In my early student teaching days, when I was at most five or six years senior to the juniors I was trying to teach, I was reading a new book, The Miner's Canary, by one of the editors-in-chief of this journal, Niles Eldredge. The book drew a very powerful analogy between the birds used to warn miners of dangerous conditions and the similar role modern species extinction should be playing for Homo sapiens in general. At the same time I was reviewing my Emerson and Hawthorne in preparation for trying to ram it down the throats of my students, transcendentalism being a famously important and potentially boring movement in English literature. Teaching in Waltham, Massachusetts, very close to Walden Pond, gave me something of an advantage when trying to impart the wisdom of these rustic Northern intellectuals, but not enough to really make the unit sing. What I needed, I realized, was well wrought, big theme modern ecology writing to insert into the English curriculum, letters of today to underline the transcendental themes of self reliance, personal connection to nature, and individual responsibility to the earth. In order to forge a connection between my students and the transcendentalists, I needed something beyond the three page excerpt of Carson's Silent Spring, which as far as my curriculum was concerned, was the first and last word on twentieth century eco-concern. I realized then that Eldredge's book highlighting the rapid demise of other species since the advent of man would fit neatly into my unit. At first, this was less revelation than it was just good teaching born of fortuitous personal investigation. What struck me next came first in the form of youthful, playful despair. Why did I have to go off on my not-so-merry photocopying own to engage my English students on modern matters of biodiversity, ecology, and global stewardship? What idea could be more important to inculcate in my willing charges than a sense that the earth would soon be wholly their own responsibility? Why was the English curriculum so silent on something so awesomely important? Here I was reading about the possibility of biotic holocaust at home, while at work, in my work of educating America's children, there was not one modern story urging stewardship, restraint or eco-concern.

But I forgot. I moved on, first to the corporate world for a brief turn and then back to teaching to take up the job of keeping Shakespeare relevant in the inner city. I concentrated on mastering my craft and basically became so absorbed in successful instruction that I stopped worrying about or questioning my specific field. I spent six years obsessing over everyone's grammar, six years emphasizing vocabulary (xenophobia anyone?), and six years contenting myself with short stories, those thumbnail sketches of all human experience. I even started to write and breezily impart my own aphorisms, like "It is your job to never make anyone's day worse." Or, "Never let them call you 'Mistah'." I progressed through the stages described above, thinking I had it all down at year one, realizing I hadn't known everything, but now did, at year five.... And that was where the continuum was supposed to stop. I could continue to refine my craft, I could always do a better job pushing "Hamlet" as the finest piece of writing the West had ever produced, and I would never fully win the mighty struggle of proving English cool, but I was certainly most of the way there, professionally. I didn't stop caring about biodiversity and environmentalism, about evolution, and man's role as steward, but I stopped looking for it and missing it when it wasn't there in the stories "they" selected from the canon for our English I-IV curricula.

Then I remembered. I don't think I even really wanted to remember, as I started approaching a decade in the biz, but it became more pronounced every year. I started to feel an absence of message in my work. Though there may be nothing new under the sun, education is a realm constantly beset by "new" ideas. Right now, in English, we are very much about theme, to the point that British literature is no longer taught chronologically, but rather through a set of vague, superimposed "themes." So you will have a unit title like "On the Edge," or "The Hero." It's one idea, I suppose. But what about the true, overarching themes of man's relationship to nature, of his natural evolution to dominance, and of his dominion over all species and the meta-ethical issues that entails? Why were these explorations totally absent from our English design? Were we really going to be able to explore the 
meaning of life without taking into consideration a single other form of it? Did it make sense to view man not in situ but rather as some lordly, lonely thing? Why would we want to take this tack? To explore our cosmic significance without ever once mentioning anything else in the cosmos besides ourselves began to seem increasingly silly. I had plenty of stories about what was happening to a man, but almost no stories about what mankind was.

I found myself thinking increasingly of transcendentalism and my first years in the field. Of Emerson saying, "Can you come to know all the birds of the forest without having killed any?" or something like that. Again, I let myself understand that science is the best window on understanding the Earth, which is where we all tread, which is thus the best way to understand man, which is the whole point of literature: to understand the experience of being alive. It was suddenly very clear to me that there have come to be unnatural divisions between the subjects, that the compartmentalizing of information has become so entrenched as to erase the interplay of information and meaning across discrete fields. I feel strongly that to put up these false barriers between Science and English in particular, any and all subjects in general, is to render the whole attempt at education increasingly very nearly meaningless. There is no deep connect between the various fields, when truly, they all play off each other in the most natural of ways. How do you understand the history of man without understanding the history of the biosphere? What is selfknowledge but the epitome of animal thought? When you rigorously consign each element of knowledge to its own classroom, what you are left with is a sort of poor cousin to rote learning - a memorizing of facts without true meaning-except that under the modern system, few can actually even repeat the facts!

There should be no barrier between the stories of man (e.g., the short works of Poe, O. Henry, Faulkner, etc.) and the stories of evolution, biodiversity, and H. sapiens' impact on and place in nature. If this seems too headslappingly obvious a statement to the informed reader, I invite you in to any modern classroom. There are no stories in Science class. There is no science in English class. Perhaps it has always been that way-but there is no good reason it should always be that way.

John Steinbeck said, in East of Eden, "Of course, people are interested only in themselves. If a story is not about the hearer, he will not listen." Steinbeck's truth underlines the challenge of teaching English: You need connections for the story to stick. But it also underlines how easy it is to make the connection between science and student, provided, that is, one frames the story correctly. The story of the world, of the natural sphere, is, of course, the story of ourselves. It is time we restore some science to the narrative of man. In America's cities, our English scores are often far from being robust, but our science scores really seem to be flatlining. Clearly, a new approach is in order, and I expect to see several innovations over the course of the next several years. Knowing education, we might even see a new approach every year. What would truly be effective, however, is simply what Steinbeck talked about: providing stories that are manifestly about the hearers. In English, we need to encourage greater exploration of the self in a grander sense than just through the prism of the "trials of man." These stories, great though they might be, are simply no longer universal enough to provide the function we intend them to. It is time now not to speak just of man, but of mankind. High school science in turn would be much easier to absorb, would be vastly more intelligible and meaningful for the modern student, if it seemed to be driving toward some meta-message. The days when students sat numbly by and let instruction wash over them is gone, if it was ever here. The students of today are both discerning and demanding; often, they will just turn off to what is not innately of interest to them. Again, what could be a more riveting tale to tell than the specter of bio-holocaust, the inter-relatedness of all life, the nobility of our species, and the mind-boggling history of all life on earth? It is critical that we begin to fit the facts into some kind of story the modern student finds compelling. Without a compelling story, the hearer simply turns away-even with the most engaging of teachers. Does anyone really think the Earth can afford to have these next generations turn away from her story?

What I am advocating is a sort of sci-integrationscience in an expanded English curriculum not to the detriment of the old masters but with an eye toward telling ever more rich, ever more true tales. Each state has subject standards that the teacher is trained to follow in the drafting of each lesson. The NJ English standards are designed to improve verbal acuity, written accuracy, and analytical capacity: I think adding just one standard for the curriculum people to write toward would go a long way to closing our science score gap, and who knows, perhaps to preserving earth's habitability as well: "Students Will be Able to Iterate a Man's Role in the Natural World." 